\title{
Antioxidant Role of Beta Carotene: Protection against Cadmium Induced Testicular Toxicity
}

\author{
Rekha Durgadas Kini", Nayanatara Arun Kumar, Anupama Noojibail, Bhagyalakhshmi K, Sneha Shetty Bhoja, \\ Pratik Kumar Chatterjee
}

\section{Rekha Durgadas Kini*, Nayanatara Arun Kumar, Anupama Noojibail, Bhagyalakhshmi K, Sneha Shetty Bhoja, Pratik Kumar Chatterjee}

Department of Physiology, Kasturba Medical College, Manipal Academy of Higher Education (MAHE), Mangalore, INDIA.

\section{Correspondence}

Dr. Rekha Durga Kini

Associate Professor, Department of Physiology, Kasturba Medical College, Manipal Academy of Higher Education(MAHE), Mangalore, INDIA.

Phone no : +919448203310

E-mail: rekha.kini@manipal.edu

History

- Submission Date: 24-02-2018

- Review completed: 14-03-2018

- Accepted Date: 12-04-2018

DOI : 10.5530/pj.2018.6s.13

Article Available online

http://www.phcogj.com/v10/i6s

\section{Copyright}

(c) 2018 Phcog.Net. This is an openaccess article distributed under the terms of the Creative Commons Attribution 4.0 International license.

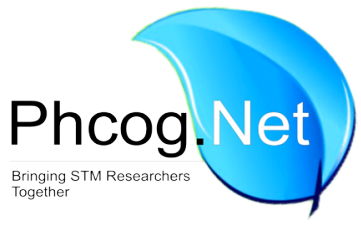

\begin{abstract}
Introduction: Cadmium $(\mathrm{Cd})$ is an industrial pollutant that affects the male reproductive system. The purpose of present study was to investigate the protective role of Beta carotene on cadmium induced testicular damage. Materials and Methods: The present study was conducted following approval from Institutional Bioethical Committee and strict internationally accepted guidelines, for the usage of animals in experimental study were. Rats were divided into four groups with 8 rats in each. The Gr. I rats were administered with the single dose of normal saline intraperitoneally. Group II received Beta carotene (10 mg/kg bw) orally for 30 days. Group III received a single dose of $1 \mathrm{mg} / \mathrm{kg}$ bw cadmium chloride and Group IV received Beta carotene for 30 days prior to cadmium administration. After the desired protocol, rats were sacrificed and both the testes were removed for biochemical and histopathological evaluation. One testis was fixed in Bouvins fluid and processed or histopathological studies. The levels of lipid peroxides (LPO) and glutathione (GSH) and superoxide dismutase (SOD) were detected in the tissue homogenates of other testis. Results: In the present study, the level of lipid peroxidation (LPO) was significantly high and GSH and SOD $(P<0.001)$ were low in cadmium treated rats compared to normal control. Pre-treatment with beta carotene showed a protective effect by decreasing LPO and increasing GS Hand SOD level $(P<0.001)$. The morphological changes like atrophy of tubules, edema and decreased spermatogenesis in the testis of rats exposed to cadmium chloride. But, antioxidant showed the normal architecture of the testis. Conclusion: Results of the present study showed the antioxidative role of beta carotene in protecting the testis from cadmium induced toxicity.

Key words: Testis, Oxidative stress, Antioxidant, Lipid peroxidation, Superoxide demutase.
\end{abstract}

\section{INTRODUCTION}

Cadmium is a heavy metal which is extremely toxic. Buildup of cadmium levels in the water, air, and soil has been occurring particularly in industrial areas. Food and cigarettes are also a significant source of cadmium exposure. ${ }^{1}$ Blood and kidney Cd levels are consistently higher in smokers than nonsmokers. Inhalation due to industrial exposure can be significant in occupational settings for example, welding or soldering, and can produce severe chemical pneumonitis. ${ }^{2}$ Aside from tobacco smokers, people who live near hazardous waste or factories that release cadmium into the air have the potential for exposure to cadmium in air. Cadmium toxicity has been demonstrated in several organs. Cadmium induces tissue injury through creating oxidative stress. ${ }^{3-5}$ Cadmium acts as a catalyst in forming reactive oxygen species. It increases lipid peroxidation, in addition it depletes antioxidants, glutathione and protein-bound sulfhydryl groups ${ }^{6}$ Testes are known to be the target organs for cadmium toxicity. The mechanisms of cadmium toxic effects on the testes involve the damage of vascular endothelium, intracellular junctions, germ cells, and Leydig and Ser- toli cells. This metal can reduce testosterone synthesis at various levels and deteriorate spermatogenesis. ${ }^{7}$ Antioxidants protect the tissue from oxidative stress. Several studies are aimed at antioxidant therapy to prevent cadmium induce dtesticular damage. ${ }^{8,9}$ However, studies regarding role of beta carotene on cadmium induced testicular toxicity are very few. Moreover, it is also seen that increasing environmental exposure to cadmium, currently existing occupational exposure and the prevalence of tobacco smoking has resulted in constant increase in the number of diagnosed fertility impairments. Hence present study was aimed to study whether pretreatment with beta carotene will be helpful in reducing cadmium induced testicular damage.

\section{MATERIALS AND METHODS}

The present study was conducted following approval from Institutional Bioethical Committeeand strict internationally accepted guidelines, for the usage of animals in experimental study were followed. Inbred adult male rats of wistar strain weighing 200- 
$250 \mathrm{~g}$ were used in the present study. Animals were housed in polypropylene cages (4-5 rats/cage) under standard laboratory conditions and fed ad libitum with commercial rodent chow (Hindustan Lever Limited) and water. Cadmium chloride ( $\mathrm{CdCl} 2$ ) (LobaChemie, India) was dissolved in normal saline. Beta carotene is dissolved in coconut oil and administered orally $(10 \mathrm{mg} / \mathrm{kg}$ bw).

Animals were divided into four groups of eight rats in each group. In the normal control group (Group I) rats were administered with the normal saline intraperitoneally. In Group-II animals received beta-carotene $(10 \mathrm{mg} / \mathrm{kg} \mathrm{bw})$ for 30 days orally. In untreated experimental control groups (cadmium treated group) rats were administered with single dose of $1 \mathrm{mg} / \mathrm{kg}$ bw (Group-III) cadmium chloride intraperitoneally. In pretreated groups rats were pretreated with beta carotene $(10 \mathrm{mg} / \mathrm{kg}$ bw) for 30 days orally and then injected with $1 \mathrm{mg} / \mathrm{kg}$ bw (Group-IV) cadmium chloride intraperitoneally.

In all the groups, rats were sacrificed under anesthesia 15 days after the final cadmium administration. Following the completion of the experimental protocol animals in each group were anaesthetized by injecting sodium pentabarbitone $(40 \mathrm{mg} / \mathrm{kg}$ bw) intraperitoneally under aseptic conditions. Laparotomy was performed, and the reproductive organs were exposed. Both the testes were removed and cleaned of fat tissue and blood, then weighed. In each group, right testis was cut into small pieces and used for biochemical analysis and left testis was used for histo-pathological studies. Pieces of the right testis were transferred into a glass homogenizer containing $10 \mathrm{ml}$ of cold phosphate buffer saline solution of $\mathrm{pH}$ 7.4. The tissue was homogenized using a manual homogenizer. The unbroken cells and cell debris were removed by centrifugation at $3000 \mathrm{rpm}$ for 10 mins by using Remi C 24 refrigerated centrifuge40C. The obtained supernatant was used for the GSH, SOD and lipid peroxide estimation. Left testis was put into a bottle containing Bouins solution for the histo-pathological analysis.

\section{Estimation of Testicular Lipid Peroxidation}

Lipid peroxidation was estimated according to the method of Kartha and Krishnamurthy. ${ }^{10}$ This assay is based on the reaction of TBA with malondialdehyde (MDA), one of the aldehyde products of lipid peroxidation.

\section{Estimation of Tissue Glutathione}

Glutathione content in the tissue homogenate $[10 \% \mathrm{w} / \mathrm{v}$ in $10 \mathrm{mM}$ potassium phosphate buffer $(7.4 \mathrm{pH})]$ was estimated by the method of Beutler et al. ${ }^{11}$

\section{Superoxide Dismutase Assay}

Superoxide Dismutase (SOD) was estimated by original method of Beauchamp and Fridovich. ${ }^{12}$

\section{Histological Slides Preparation}

Specimens from testicular tissues were fixed in Bouins solution and dehydrated in ascending grades of ethanol alcohols, cleared in xylol, casted, blocked, cut at 2-5 $\mu \mathrm{m}$ thickness and stained with hematoxylineosin for microscopic examination. ${ }^{13}$

\section{Statistical Analysis}

Values were expressed in mean \pm SEM. SPSS version II was used for statistical analysis. Differences between groups were assessed by oneway analysis of variance. The Post Hoc (LSD) test was used for intergroup comparison. $P<0.05$ was taken as significant.

\section{RESULTS}

\section{Biochemical Results}

The levels of LPO in the tissues homogenates of testes were significantly higher in cadmium-group than control group. Pre-treatment with beta carotene prior to cadmium administration showed significant decrease in the level of lipid peroxide. The levels of GSH and SOD in the tissues homogenates of testes were significantly declined in Cadmium-group comparing with controls. In the rats, pretreated beta carotene the levels of GSH and SOD were significantly elevated in comparison with cadmium-treated group (Table1).

\section{Histopathological Results}

The testes of normal control rats showed the normal architecture of the testes (Figure 1). No detectable histological alterations showed in the testes of rats pretreated with beta carotene (Figure 2). The testes of male albino rats intoxicated with cadmium chloride alone showed decreased spermatogenesis(less than $10 \%$ of tubule) and atrophy of the tubules (Figure 3). Testes of the rats pretreated with beta carotene prior to cadmium administration were normal and showed spermatogenesis in more than $50 \%$ of the tubule and interstitial cells were normal(Figure 4 ).

\section{DISCUSSION}

Cadmium is widely distributed in the environment because of its many industrial applications. The health risk to humans from acute and chronic cadmium exposure has been well documented. Previously, Mueller (1986) reported that single-dose cadmium administration increased lipid peroxidation and decreased GSH in the liver. ${ }^{14}$ Many investigators reported that the reduction of GSH levels leads to elevation of LPO. ${ }^{15,16}$ The present study demonstrated that the levels of GSH and SOD in the tissues homogenates of testes were significantly declined in cadmiumgroup comparing with controls. Various mechanisms were suggested to be responsible for the cadmium toxicity. One of these mechanisms includes cadmium binding to-SH groups from cell membrane proteins, cytoplasmic proteins, and enzymes. In addition, cadmium can reduce activities of several enzymes including enzymes antioxidants in addition, the authors showed that in vitro and in vivo cadmium administration in

Table 1: Effects of pretreatment with beta carotene for 30 days prior to cadmium administration on rat testis. The values are expressed as mean \pm SEM. In each group eight animalwas used. NS= not significant versus Gr.I. *** $p<0.001$ versus Gr.I and Gr.ll. www $p<0.001$ versus Gr. III.

\begin{tabular}{ccccc}
\hline variables & Group I & Group II & Group III & Group IV \\
\hline MDA(nmol/gm wet tissue) & $5.113 \pm 0.277$ & $5.121 \pm 0.261 \mathrm{NS}$ & $26.687 \pm 1.229^{* * *}$ & $5.826 \pm 2.168 \mathrm{www}$ \\
GSH( nmol/mg protein) & $5.951 \pm 0.379$ & $5.405 \pm 0218 \mathrm{NS}$ & $3.570 \pm 0.08^{* * *}$ & $5.970 \pm 0.341 \mathrm{www}$ \\
SOD(units/gm protein) & $12.451 \pm 0.51$ & $12.4980 .428 \mathrm{NS}$ & $7.496 \pm 0.376^{* * *}$ & $12.548 \pm 0.624 \mathrm{www}$ \\
\hline
\end{tabular}




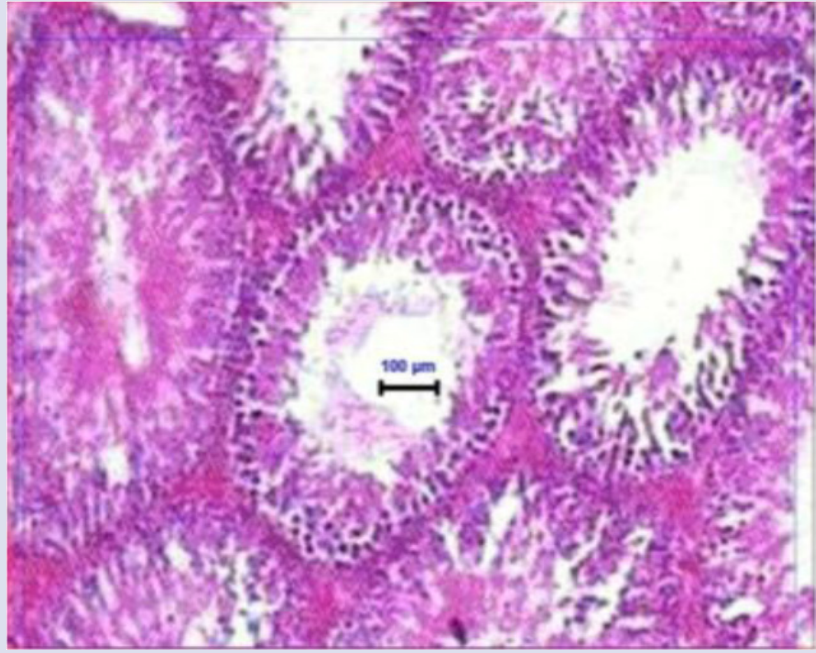

Figure 1: Testes of male albino rats treated with $0.9 \%$ saline showing normal structure of seminiferous tubules ( $\mathrm{H}$ and $\mathrm{E} ; 10 \mathrm{X})$. Scale bar $100 \mu \mathrm{m}(\mathrm{Gr} . \mathrm{I})$.

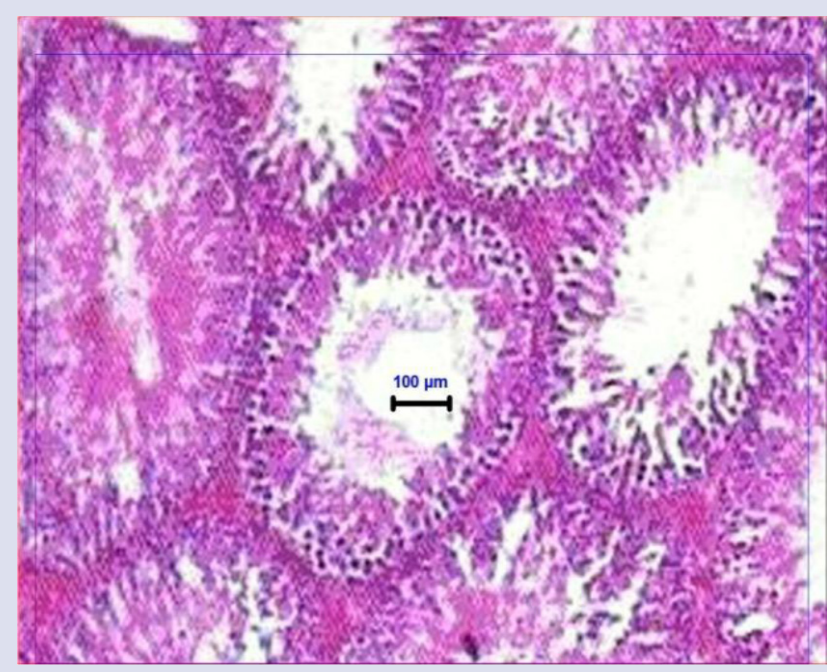

Figure 2: Testes of male albino rats treated with beta carotene showing normal structure of seminiferous tubules ( $\mathrm{H}$ and $\mathrm{E} ; \mathrm{10X})$. Scale bar $100 \mu \mathrm{m}$ (Gr.l). rats increased tissue lipid peroxidation. ${ }^{17}$ In agreement with the previous results, the current study revealed that the levels of LPO were significantly higher in cadmium group than control group in the tissues homogenates of testes. Aruld has reported that oxidative stress by free radical toxicity caused by cadmium affected infertility. ${ }^{18}$ Stajn et al. reported that different doses of cadmium increase organ lipid peroxidation (LPO) in many organs including male sex organs and brought about changes in the antioxidant defense system. ${ }^{19,20}$ Claimed that even with low doses of cadmium chloride ( $1 \mathrm{mg} / \mathrm{kg}$ for one month) induced lack of spermatogenesis and severe necrosis of the testes of rats. ${ }^{20}$ Moreover, Santos et al. reported that endothelial damage of the small blood vessels, edema and hemorrhage of the rat testes can be demonstrated by using just a single parenteral dose of cadmium chloride at $2-4 \mathrm{mg} / \mathrm{kg} .{ }^{21}$ The result of the present study showed histological changes like decreased spermatogenesis (less than $10 \%$ of tubule) and atrophy of the tubules.

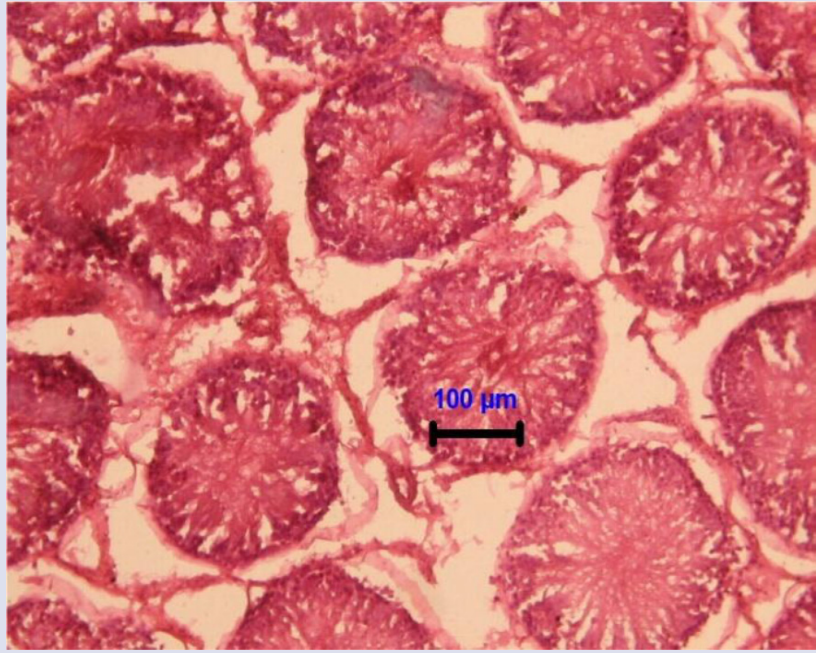

Figure 3: Testes of male albino rats with cadmium administration showing decreased spermatogenesis and atrophy of the tubules $(H$

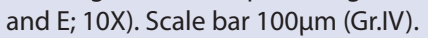

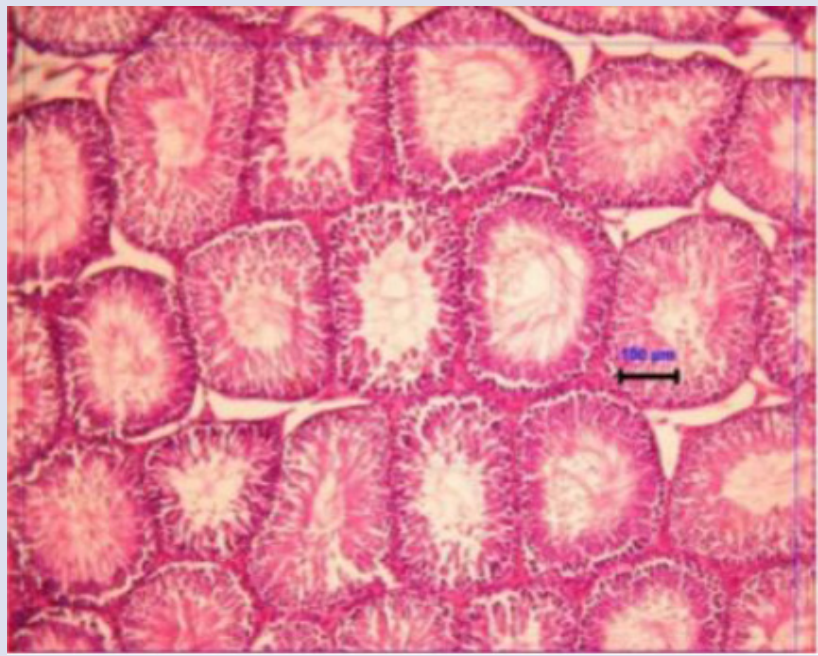

Figure 4: Testes of male albino rats treated with beta carotene prior to cadmium administration showing normal structure of seminiferous

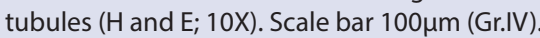

In the present study, pretreatment with beta carotene prior to cadmium administration showed a significant reduction in the levels of LPO compared to cadmium treated group. The levels of GSH and SOD in rats pretreated with beta carotene prior to cadmium administration were significantly elevated in comparison with cadmium treated group. The present study also revealed the pretreatment with beta carotene prior to cadmium administration showed the normal architecture of the testis.

\section{CONCLUSION}

Hence, the result of the present study demonstrated the protective role beta carotene on cadmium chloride induced testicular damage.

\section{CONFLICT OF INTEREST}

The authors declare no conflict of interest. 


\section{ABBREVIATIONS}

Cd: Cadmium; SOD: Superoxide Desmutase; GSH: Reduced Glutathione; LPO: LipidPeroxidation.

\section{REFERENCES}

1. Jarup L. "Health effects of cadmium exposure-a review of the literature and a risk estimate". Scandinavian Journal of Work, Environment and Health.1998;24:1-51.

2. Nordberg GF, Nogawa K, Nordberg N, Friberg L. "Cadmium," in Chapter 23 in Handbook of the Toxicology of Metals Eds, Elsevier, Amsterdam. The Netherlands, 3rd edition. 2007;445-86.

3. Matovic $V$, Buha $A$, Bulat $Z$, Dukic $C D$. "Cadmium toxicity revisited: Focus on oxidative stress induction and interactions with zinc and magnesium". Arhiv Za Higijenu Rada I Toksikologiju. 2011;62(1):65-76

4. Patra RC, Rautray AK, Swarup D. "Oxidative stress in lead and cadmium toxicity and its amelioration." Veterinary Medicine International. 2011;4:44-8.

5. Cuypers A, Plusquin M, Remans T,et al. "Cadmium stress: An oxidative challenge". Bio Metals. 2010;23(5):927-40.

6. Flora SJS, Megha M, Ashish M. Heavy metal induced oxidative stress and its possiblereversal by chelation therapy. Indian J Med Res.2008;128(4):501-23.

7. Martynowicz H, Skoczy SA, Karczmarek WB, Andrzejak R. Effects of Cadmium on testis function. Med Pract. 2005:56(2):167-74

8. Yan LJ, Hua W, Cheng Z, Ying Z, Mei Z, Yuan HC, et al. Nacetylcysteine protects against cadmium induced germ cell apoptosis by inhibiting endoplasmic reticulum stress in testes. Asian J Androl. 2009:15(2):290-6.

9. Rekha DK, Tripathi Y, Raghuveer CV, Sheila RP, Ramaswamy C, Priya K. Role of vitamin $\mathrm{C}$ as an antioxidant in cadmium chloride induced testicular damage. Int J ApplBiol Pharmaceut Sci. 2011;29(3):484-8.

10. Kartha $R$, Krishnamurthy S.Factor's affecting in vitro lipid peroxidation in rat brain homogenate. Ind J Physiol Pharmacol. 1978;22(1):44-52

11. Beutler $E$, Duron O, Kelly BM. Improved method for determination of blood glutathione. J Lab Clin Invest. 1963;61(5):882-8.

12. Beauchamp C. Fridovich I. Superoxide dismutase,improved assay and an assay applicable to acrylamide gel. Ann Biochem. 1971;44(1):276-87.

13. Culling CFA, Allison RT, Batt WT. Cellular pathology techniques, $14^{\text {th }}$ ed. Butter worths. 1985

14. Mueller L. Consequences of cadmium toxicity in rat hepatocytes:mitochondria dysfunction and lipid peroxidation. Toxicol. 1986;40(3):285-95.

15. Bagchi D, Bagchi M, Hassoun EA, Stohs SJ. Cadmium induced excretion of lipid metabolites,DNA damage, Glutathione depletion and hepatic lipid peroxidation in Sprague Dawely rats. Biol Trace Elem Res. 1996;52(2):143-54.

16. El-Maraghy SA, Gad MZ, Fahim AT, Hamdy MA. Effect of cadmium and aluminium intake onantioxidant status and lipid peroxidation in rat tissues. J Biochem Mol Toxicol. 2001;15(4):207-14

17. Xiao $P$, Jia $X D$, Zhong WJ, Jin XP, Nordberg G.Restorative effects of zinc and selenium on cadmium induced kidney oxidative damage rats. Biomed Environ Sci. 2002:15(1):67-74

18. Aruldhas MM, Subramanian S, Seker P, Vengatesh G, Chandrahasan G Govindarajulu $P$, et al. Chronic Chromium exposure induced changes in testicular histoarchitechture are associated with oxidative stress-a study in non-human primates. Hum Reprod. 2005;20(10):2801-13.

19. Stajn A, Zikic R, Ognjanovic VB, Saicic ZS, Pavlovic SZ, Kostic MM, et al. Comp Biochem Physiol C. Pharmacol Toxicol Endocrino. 1997;117(2):167-72.

20. Blanco A, Moyano R, Vivo J, Flores AR, Molina A, Blanco C, et al. Quantitative changes in the testicular structure in mice exposed to loe doses of cadmium Environ Toxicol Pharmacol. 2007:23(1):96-101.

21. Santos FW, Oro T, Zeni G, Rocha JBT. Do Nascimento PC and Nogueira CW Cadmium induced testicular damage and its response to administration of succimer and diphenyl disclenide in mice.Toxicol Lett. 2004;152(3):255-63.

\section{GRAPHICAL ABSTRACT}

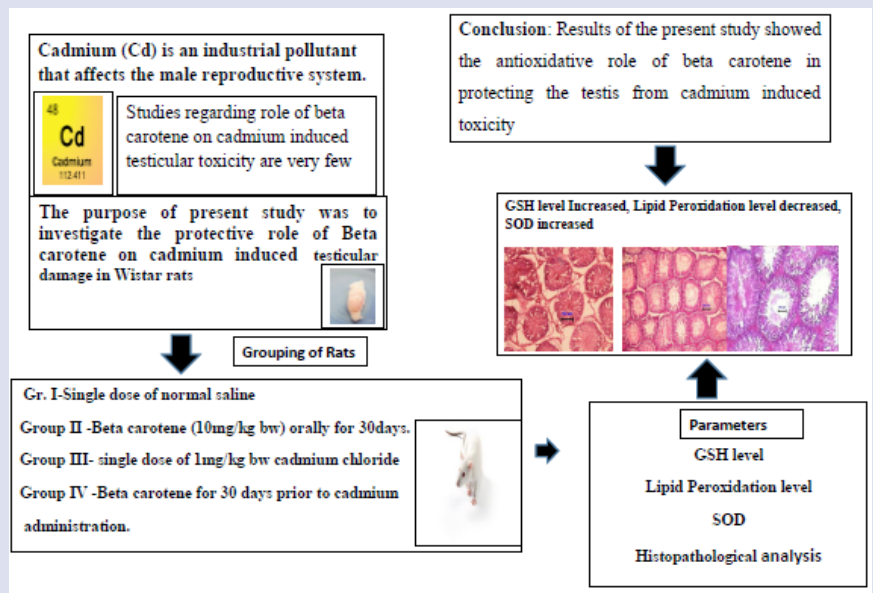

\section{SUMMARY}

Thus in summary the present study emphasizes the toxic effect of cadmium on testis and protective role of beta carotene on reducing the toxic effects odf cadmium chloride.

\section{ABOUT AUTHORS}

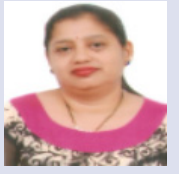

Dr. Rekha Durgadas Kini: Is currently working as Associate Professor of Physiology, Kasturba Medical College Mangalore, Manipal Academy of Higher Education, India. She is a recognized $\mathrm{PhD}$ guide of Manipal Academy of higher education. Her research area is mainly focused on toxicology and free radical,Stress. She has more than 30 research publications in indexed journals.

Dr .Nayanatara Arun Kumar: Is currently working as Associate Professor of Physiology, Kasturba Medical College Mangalore, Manipal Academy of Higher Education. She is a recognized PhD guide of Manipal Academy of Higher Education. Her research area is mainly focused on stress, Radio protective effects of herbal extracts, neurophysiology, stress, food additives and alcohol. She has more than 80 research publications in indexed journals. She has been working as a Principal Investigator for BRNS funded project

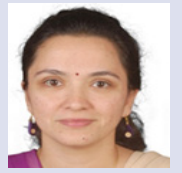

Dr Anupama N: Is currently working as Associate Professor, Department of Physiology Kasturba Medical College ,Mangalore Manipal Academy of Higher Education, India. She received her MBBS degree from Bangalore University in 1999 and MD (Doctor of Medicine) in Physiology from MAHE University in 2004. Her research interest includes Respiratory Physiology obesity and animal studies.

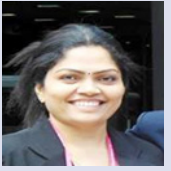

Dr Bhagyalakshmi K: Is currently working as Professor and Head of the Department of Physiology, Kasturba Medical College Mangalore, Manipal Academy of Higher Education, India. She received her MBBS degree from Mysore University in 1999 and MD (Doctor of Medicine) in Physiology at MAHE University, Manipal in 2005 Her research interest includes Heart rate variability, Yoga obesity and animal studies. She is the recognized PhD guide of Manipal Academy of Higher Education 


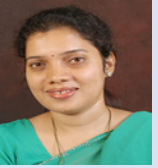

Dr Sneha Shetty Bhoja: Is currently working as Associate Professor, Department of Physiology, Kasturba Medical College,Mangalore, Manipal Academy of Higher education, India. She completed her MBBS in 2003 from Bangalore University and MD (Physiology) in 2008 from Manipal University. Her research of interest includes Cardio Vascular Physiology and Yoga.

Dr. Pratik Kumar Chatterjee Chatterjee: Is currently working as Associate-Professor, Department of Physiology, Kasturba Medical College (KMC), Mangalore, Manipal Academy of Higher Education (MAHE), Karnataka, India. : He has obtained his MBBS degree from Manipal College of Medical Sciences Pokhara, Kathmandu-University (KU), Nepal, in the year 2006 and then MD (Physiology) from Kasturba Medical College (KMC), Manipal, Manipal-Academy of Higher Education (MAHE). He is actively involved in research activities, field of interest being toxicology, diabetes and cancer.

Cite this article: Kini RD, Kumar NA, Noojibail A, Bhagyalakhshmi K, Bhoja SS, Chatterjee PK. Antioxidant Role of Beta Carotene: Protection against Cadmium Induced Testicular Toxicity. Pharmacog J. 2018;10(6)Suppl:s66-s70. 